\title{
PENGEMBANGAN LEMBAR KERJA SISWA (LKS) MATEMATIKA BERBASIS DISCOVERY LEARNING PADA MATERI STATISTIKA UNTUK SISWA KELAS IV SD
}

\author{
Duwi Liana Anggela ${ }^{1}$, Tio Gusti Satria ${ }^{2}$, Riduan Febriandi ${ }^{3}$ \\ 1,2,3 PGSD STKIP-PGRI Lubuklinggau
}

Email: anggela289@gmail.com ${ }^{1}$, satriagustio@gmail.com² riduanfebriandi9@gmail.com ${ }^{3}$

\begin{abstract}
This study aims to develop a Discovery Learning-Based Mathematics LKS (LKS) on Statistical Materials for Grade IV Students at the State Elementary School 46 Lubuklinggau which is valid and practical. The type of research is Research and Development with a 4-D development model. The results of the validation of linguists, materials experts and media experts with a fairly high validity interpretation. Overall the validation results from the experts are in the good category (high enough). Meanwhile, the small group practicality test and the teacher response practicality test were categorized as very practical. It was concluded that the Discovery Learning-Based Mathematics Student Worksheet (LKS) on Statistics Materials for Grade IV Students at the 46 Lubuklinggau State Elementary School was valid and practical to use.
\end{abstract}

Keywords: Development, Student Worksheets, Discovery Learning.

\begin{abstract}
ABSTRAK
Penulisan ini bertujuan untuk mengembangkan LKS (LKS) Matematika Berbasis Discovery Learning pada Materi Statistika untuk Siswa Kelas IV SD Negeri 46 Lubuklinggau yang valid dan praktis. Jenis penulisan yaitu Research and Development (Pengembangan) dengan model pengembangan 4-D. Hasil validasi ahli bahasa, ahli materi dan ahli media dengan interpretasi validitas cukup tinggi. Secara keseluruhan hasil validasi dari para ahli masuk dalam kategori baik (cukup tinggi). Sedangkan untuk uji coba kepraktisan small group dan uji kepraktisan respon guru dikategorikan sangat praktis. Disimpulkan bahwa Lembar Kerja Siswa (LKS) Matematika Berbasis Discovery Learning pada Materi Statistika untuk Siswa Kelas IV SD Negeri 46 Lubuklinggau valid dan praktis untuk digunakan.
\end{abstract}

Kata Kunci: Pengembangan, Lembar kerja Siswa, Discovery Learning.

\section{PENDAHULUAN}

Pendidikan merupakan usaha sadar dan terencana untuk mewujudkan suasana belajar dan proses pembelajaran agar peserta didik secara aktif mengembangkan potensi dirinya untuk memiliki kekuatan spiritual keagamaan, pengendalian diri, kepribadian, kecerdasan, akhlak mulia, serta keterampilan yang diperlukan dirinya, masyarakat, bangsa dan Negara (Kemdiknas dalam Hendriana \& Jacobus, 2016:26). Oleh karena itu dalam pendidikan diperlukannya seorang pendidik untuk membuat peserta didik dari yang tidak tahu menjadi tahu serta dapat mengembangkan potensi yang dimiliki oleh peserta didik. Hal ini sejalan dengan pendapat Aziz (2017:174) pendidik adalah seseorang yang berperan dalam proses pendidikan peserta didik. Pendidik sangat berperan penting dalam proses pembelajaran agar tujuan dari pembelajaran tersebut tercapai.

Proses pembelajaran merupakan proses dimana terjadinya transfer ilmu antara pendidik dan peserta didik. Menurut Pane dan Dasopang (2017:334) Pembelajaran adalah proses interaksi peserta didik dengan pendidik, dengan bahan ajar, metode penyampaian, strategi pembelajaran, dan sumber belajar dalam suatu belajar dalam suatu lingkungan belajar. Proses pembelajaran yang di harapkan yaitu terjadinya 
interaksi antara pendidik dan peserta didik dengan harapan tujuan yang telah dirumuskan dapat tercapai. Untuk mencapai tujuan dari pembelajaran tersebut, guru sebagai pendidik harus melakukan proses pembelajaran yang aktif, kreatif dan menyenagkan. Adapun untuk menunjang pembelajaran yang aktif, kreatif dan menyenangkan yaitu pendidik menggunakan sumber belajar yang menarik minat siswa.

Musfiqon (2012:130) Sumber belajar adalah segala sumber daya (resources) yang meliputi materi pembelajaran, manusia, alat, teknik, dan lingkungan yang dapat digunakan untuk mendukung pencapaian tujuan pembelajaran. Sedangkan Ikhsan, dkk (2017:3) sumber belajar merupakan kebutuhan penting yang bisa dijadikan sumber informasi. Disimpulkan bahwa sumber belajar merupakan segala sesuatu baik itu berupa materi pembelajaran, manusia, yang dapat dijadikan sebagai sumber infomasi dalam belajar. Sumber belajar memiliki peranan yang sangat penting dalam menunjang proses pembelajaran. Setiap mata pelajaran membutuhkan sumber belajar dalam membantu proses pembelajaran. Salah satunya pada pembelajaran Matematika.

Matematika merupakan mata pelajaran yang dipelajari disetiap jenjang pendidikan dari tingkat SD sampai SMA bahkan perguruan tinggi. Menurut Risnawati (Arifin dan Sepriyani, 2019:9) Pembelajaran Matematika juga merupakan bagian dari ilmu dasar yang bertujuan untuk membekali siswa agar berpikir logis, analitis, sistematis, kritis dan kreatif serta kemampuan kerjasama. Sedangkan menurut Sintawati. dkk (2020:94) Matematika merupakan salah satu ilmu pengetahuan dasar yang bermanfaat bagi kehidupan sehari-hari.

Berdasarkan hasil observasi dan wawancara yang dilakukan di SD Negeri 46 Lubuklinggau dengan guru kelas IV.a Ibu Citra Haziariah, S.Pd. pada tanggal 28 November 2020 diperoleh informasi jumlah siswa kelas IV.a terdiri dari 26 siswa. Sedangkan untuk permasalahan di sekolah tersebut yaitu terletak pada bahan ajar yang digunakan dan faktor dari siswa itu sendiri. Bahan ajar yang di gunakan hanyalah buku dari pemerintah dan sedikit tambahan dari referensi yang dimiliki oleh wali kelas IV.a. Dalam penerapan proses pembelajaran guru telah menggunakan model Kontekstual yang mengaitkan dengan kehidupan sehari-hari siswa akan tetapi, siswa memiliki kendala tersendiri seperti minat belajar siswa, motivasi dalam belajar dan latar belakang dari siswa terkhusus dalam pembelajaran Matematika.

Siswa dalam proses pembelajaran hanya terfokus pada apa yang diberikan guru saja dan buku yang digunakan pun sulit untuk dipahami serta kurang menarik. Sehingga siswa kurang bersemangat dalam belajar Matematika dan membuat proses pembelajaran kurang efektif dan mengakibatkan hasil belajar siswa pun rendah. Oleh karena itu dibutuhkan sumber belajar yang dapat membangkitkan minat belajar dan motivasi belajar siswa khususnya dalam pembelajaran Matematika. Salah satu sumber belajar yang dapat digunakan adalah Lembar Kerja Siswa.

Fitria (2018:8) mengemukakan bahwa Lembar Kerja Siswa (LKS) adalah sarana belajar berupa lembaran-lembaran yang berisi tugas siswa dan latihan-latihan yang telah dikemas sedemikian rupa oleh guru untuk siswanya serta mengacu pada kompetensi dasar untuk mencapai tujuan pembelajaran. Penggunan LKS dalam proses belajar mengajar dapat memberikan kemudahan untuk siswa memahami materi dan melatih siswa untuk berpkir kritis dalam menyelesaikan soal-soal yang terdapat di dalam LKS yang disediakan. Matematika pembelajaran yang sulit bagi siswa. Sejalan dengan pendapat Ismatulloh (2017:25) Matematika adalah pembelajaran yang sulit, membosankan dan membutuhkan pemikiran yang ekstra untuk dapat mampu memahami materinya. Oleh karena itu dibutuhkan penerapan model pembelajaran 
yang mendorong siswa untuk lebih aktif dan mencari tahu sendiri tentang materi yang akan dipelajari yang tahap awalnya guru memberikan rangsangan terlebih dahulu tanpa memberikan petunjuk yang terlalu mengarah pada materi yang akan diajarkan. Adapun model pembelajaran yang sesuai untuk diterapkan adalah model Discovery Learning. Menurut Fitriyana dan Purwasih (2018:306) LKS Matematika Berbasis Discovery Learning merupakan LKS yang menuntun siswa melakukan eksperimen dan penemuan, sehingga sebelum konsep Matematika itu diberikan terlebih dahulu siswa menemukan sendiri konsep dasarnya malalui percobaan.

Discovery Learning (Cintia dkk, 2018:71) merupakan model yang mengarahkan siswa menemukan konsep melalui berbagai informasi atau data yang diperoleh melalui pengamatan atau percobaan. Pembelajaran Discovery Learning ini merupakan rangkaian kegiatan pembelajaran dimana guru menyajikan bahan ajar tidak dalam bentuk final atau menjelaskan secara rinci, tetapi guru memberikan peluang untuk mencari dan menemukan sendiri konsep terhadap materi yang sedang dipelajari. Dengan menerapkan pembelajaran ini, siswa akan dilatih untuk belajar mandiri dan mengkonstruksi pengetahuan yang diperoleh dari hasil pemikiran mereka sendiri serta terlatih dalam menyelesaikan masalah yang dihadapi. Sejalan dengan Rosarina, dkk (2016:374) Discovery Learning merupakan suatu model pemecahan masalah yang akan bermanfaat bagi anak didik dalam menghadapi kehidupannya di kemudian hari.

Berdasarkan uraian di atas, maka diperlukan suatu pengembangan bahan ajar Matematika Berbasis Discovery Learning atau penemuan, agar siswa lebih termotivasi untuk mencari tahu langkah demi langkah dalam menyelesaikan permasalahan pada pembelajaran Matematika. Siswa akan dibiasakan untuk berpikir kritis, sehingga kata sulit dalam pembelajaran Matematika pun akan berkurang. Oleh karena, itu penulis tertarik untuk melakukan penulisan yang berjudul: "Pengembangan Lembar Kerja Siswa (LKS) Matematika Berbasis Discovery Learning pada Materi Statistika untuk Siswa Kelas IV SD Negeri 46 Lubuklinggau.”

\section{METODOLOGI PENELITIAN}

Model Pengembangan
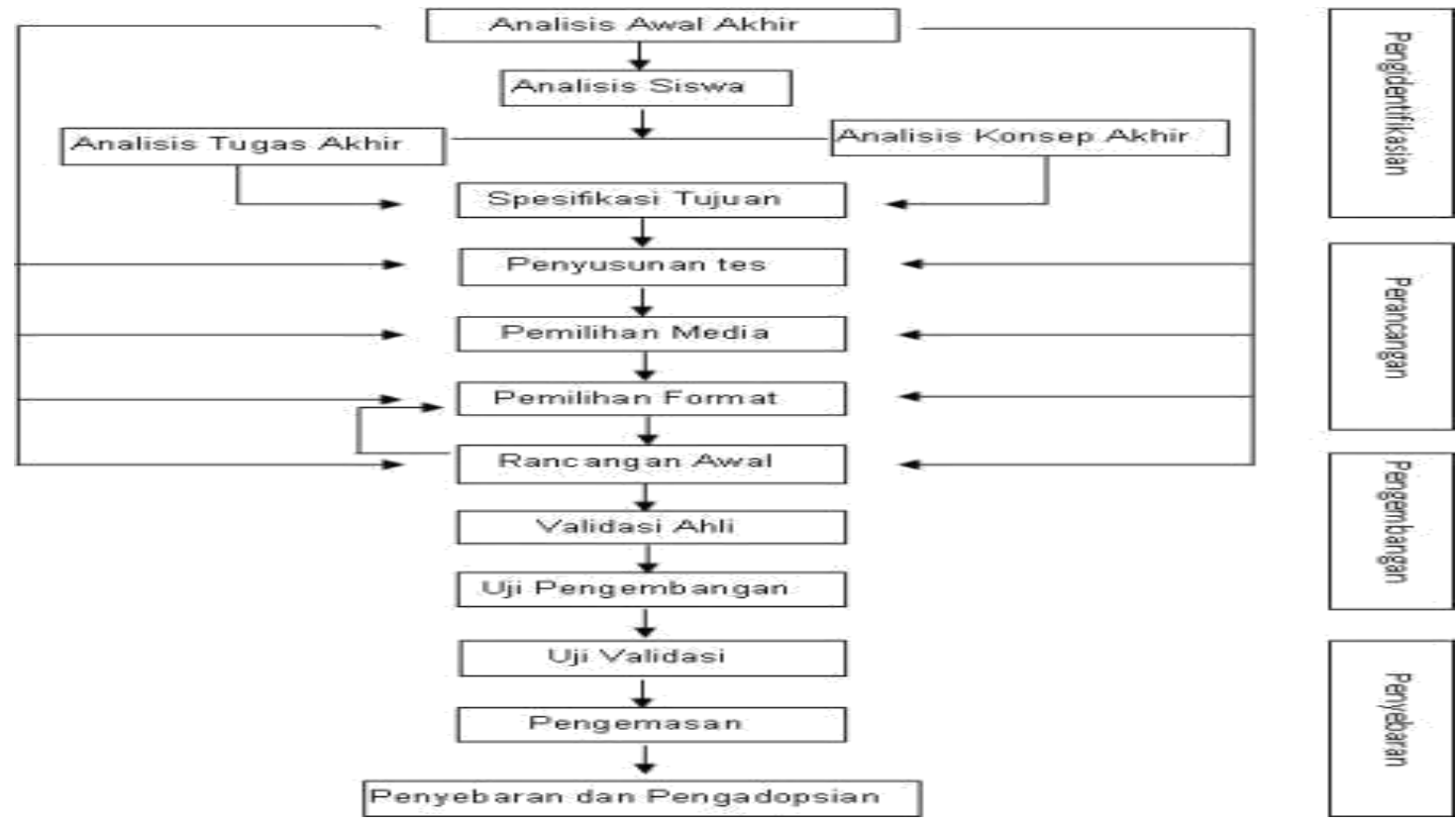

Gambar 1 Model Pengembangan Perangkat Pembelajaran 4-D

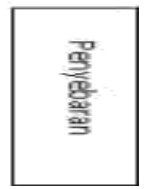

Volume: 4 No. 2 Juli 2021

JURNAL ILMIAH AQUINAS Terbit Juli dan Januari Setiap Tahunnya 


\section{Prosedur Pengembangan}

Metode penulisan yang digunakan dalam penulisan ini adalah Research \& Development (R\&D). Penulisan ini bertujuan untuk menghasilkan bahan ajar berupa LKS yang layak dan praktis untuk menunjang dalam proses pembelajaran Matematika pada materi Statistika kelas IV SD, serta meningkatkan hasil belajar siswa. Penulis memilih menggunakan model pengembangan 4-D pada penulisan ini untuk dijadikan sebagai dasar mengembangkan LKS Matematika Berbasis Discovery Learning. Model pengembangan 4-D memiliki empat tahapan dalam pengambangan, tetapi karena penulis memiliki berbagai keterbatasan, maka dalam penulisan ini hanya dilakukan dengan 3 tahapan yaitu, tahap Pendefinisian, Perancangan dan tahap Pengembangan (modifikasi Thiagarajan dan Semmel dalam Trianto, 2010:189).

\section{Uji Coba Desain}

\section{Desain Uji Coba}

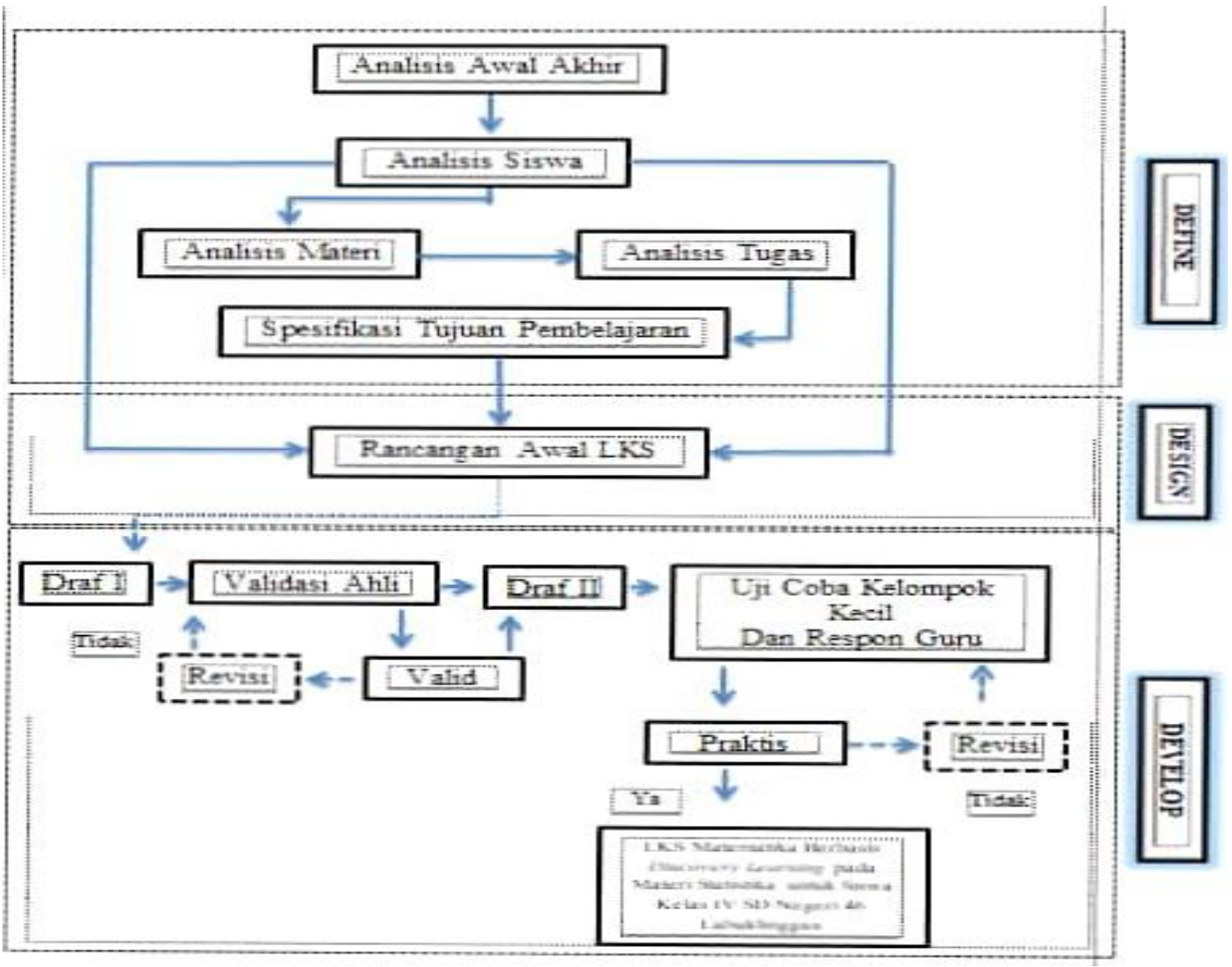

\section{Gambar 2. Alur Pengembangan LKS Modifikasi dari Model 4-D (Aidah, 2016:4)}

\section{Subjek Uji Coba}

Adapun subjek penulisan ini adalah Ahli atau pakar siswa kelas IV.SD, Guru Kelas IV SD yang dapat dijadikan pedoman dalam melakukan pengbangan LKS. Untuk subjek uji coba Ahli itu terbagi manjdi 3, yaitu:
1. Ahli Media
2. Ahli Bahasa
3. Ahli materi 
Subjek uji coba siswa dan uji coba guru:

1. Subjek uji coba respon guru kelas IV.

2. Uji coba kelompok kecil terdiri dari 6 orang.

\section{Instrumen Pengumpulan Data}

Instrumen pengumpulan data yang penulis gunakan pada pengembangan LKS

Matematika Berbasis Discovery Learning pada Materi Statistika untuk Kelas IV SD Negeri 46 Lubuklinggau yaitu: Wawancara, Kuisioner (Angket).

1. Wawancara

Wawancara adalah kegiatan yang dilakukan antara dua orang atau lebih untuk mencari tahu suatu informasi yang mendalam melalui serangkaian pertanyaanpertanyaan pada seseorang yang ingin diajukan pertanyaan.

2. Kuisioner (Angket)

Kuisioner atau angket teknik analisis data dengan cara memberikan beberapa pertanyaan guna memperoleh informasi dari responden yang belum diketahui oleh penulis. Kuesioner di berikan kepada angket tanggapan siswa, angket respon guru dan angket validasi produk kepada para ahli media dan ahli materi .

a. Lembar validasi

Lembar validasi digunakan untuk mendapatkan validasi dari ahli tentang kualitas LKS Berbasis Discovery Learning. Lembar validasi ini berbentuk checklist. Adapun Lembar validitas ini terdiri dari dua macam yaitu, lembar validitas ahli media dan lembar validitas ahli materi pembelajaran. Berikut ini kisi-kisi Media, bahasa dan materi.

b. Lembar Angket Guru

Data kuantitatif skor penilaian yang diperoleh dari hasil pengisian lembar angket kelayakan yang diisi oleh guru akan dianalisis dengan acuan yang diadaptasi menggunakan skala Likert yang nantinya akan dideskripsikan secara kualitatif. Angket ini digunakan untuk mengetahui kelayakan LKS Berbasis Discovery Learning yang dikembangkan. Angket kelayakan ini diberikan kepada guru setelah menggunakan LKS yang dikembangkan.

c. Lembar Angket Peserta Didik

Lembar angket peserta didik diberikan kepada peserta didik setelah mereka menggunakan atau mengikuti pembelajaran dengan menggunakan media tersebut. Lembar angket peserta didik berbentuk checklist.

\section{Teknik Analisis Data}

Adapun teknik analisi data yang digunakan oleh penulis yaitu, teknik deskriptif kuantitatif. Teknik analisis ini digunakan untuk mengolah data yang diperoleh melalui angket dalam bentuk deskriptif persentase. Sejalan dengan pendapat Solikha (2016:345) adalah statistik yang mempunyai tugas mengorganisasi dan menganalisis data, angka, agar dapat memberikan gambaran secara teratur. Menurut Fajriyanti (2018:152) Data yang diperoleh dengan teknik kuisioner atau angket ini dianalisis dengan teknik deskriptif. Data kualitatif yang berupa pernyataan sangat kurang, kurang, baik dan sangat baik yang kemudian diubah menjadi data kuantitatif berupa skor penilaian, sangat kurang $=1$, kurang $=2$, baik $=3$ dan sangat baik $=4$ (penilaian untuk para ahli). Sedangkan untuk respon siswa menggunakan skala Guttman yaitu jawaban "Ya" (1) dan "Tidak" (0). untuk respon siswa. 


\section{Analisis Kevalidan}

Proses dari validasi ini yaitu dengan cara mengumpulkan data dari para ahli (validator) menggunakan angket. Adapun data yang diperoleh akan menjadi panduan oleh penulis untuk melakukan evaluasi dan revisi terhadap bahan ajar yang akan dikembangkan. Angket untuk para ahli terbagi menjadi tiga yaitu angket ahli bahasa, ahli materi dan media. Adapun langkah-langkahnya sebagai berikut:

1. Menghitung jumlah skor jawaban yang diperoleh dari angket dan menentukan skor totalnya. Adapun pemberian skor menggunakan skala likert 1-4 dengan jawaban kurang baik $=1$, cukup baik $=2$, baik $=3$ dan sangat baik $=4$.

2. Langkah selanjutnya pemberian nilai validitas dengan rumus berikut:

$\mathbf{V}=\sum \boldsymbol{S} /[\mathbf{n}(\mathbf{c}-\mathbf{1})] \ldots . . . . .$. Azwar (2015:113)

\section{Keterangan:}

$\mathrm{V}=$ Nilai kevalidan

$\mathrm{S}=\mathrm{r}-\mathrm{lo}$

lo = Angka penilaian validitas yang terendah (dalam hal ini $=1$

$\mathrm{c}=$ Angka penilaian validitas yang tertinggi (dalam hal ini $=4)$

$r$ = Angka yang diberikan oleh seorang penilai

3. Mencocokkan rata-rata validitas dengan kriteria kevalidan LKS.

Tabel 1. Interpretasi Validitas Aiken's $V$

\begin{tabular}{cc}
\hline Koefisien Korelasi & Interpretasi Validitas \\
\hline$>0,80$ & Tinggi \\
\hline $0,60 \leq V<0,80$ & Cukup Tinggi \\
\hline $0,40 \leq V<0,60$ & Cukup \\
\hline $0 \leq V<0,40$ & Buruk \\
\hline & Sumber: Febriandi, dkk. (2019:152)
\end{tabular}

Analisis Kepraktisan

Praktikalitas adalah tingkat keterpakaian dan keterlaksanaan prototype perangkat pembelajaran oleh guru dan siswa, yaitu melaksanakan eksperimen pengajaran dengan menggunakan perangkat pembelajaran yang telah direvisi berdasarkan penilaian dari validator. Analisis kepratisan LKS dapat dilihat dari respon siswa. Adapun yang harus dilakukan untuk menguji kepraktisan adalah sebagai berikut:

1. Menghitung jumlah skor jawaban yang diperoleh dari angket dan menentukan skor totalnya. Adapun pemberian skor untuk setiap item dengan jawaban "Ya" (1) dan "Tidak" (0). Langkah selanjutnya memberikan persentase nilai.

Tingkat Praktikalitas $=\frac{\text { Jumlah skor yang diperoleh }}{\text { Jumlah skor total }} \times 100 \%$

2. Menginterpretasikan data

Tabel 2. Kriteria Tingkat Kepraktisan

\begin{tabular}{ccc}
\hline No & Nilai Akhir & Kategori \\
\hline 1 & $81 \%-100 \%$ & Sangat praktis \\
\hline 2 & $61 \%-80 \%$ & Praktis \\
\hline
\end{tabular}




\begin{tabular}{ccc}
\hline 3 & $41 \%-60 \%$ & Cukup praktis \\
\hline 4 & $21 \%-40 \%$ & Kurang praktis \\
\hline 5 & $0 \%-20 \%$ & Tidak praktis \\
\hline
\end{tabular}

\section{HASIL PENELITIAN DAN PENGEMBANGAN}

Penulis telah melaksanakan tahapan sesuai dengan penelitian pengembangan yang penulis ambil yaitu tahapan model pengembangan 4-D. Penelitian ini melaksanakan beberapa tahapan guna menghasilkan LKS yang valid dan praktis. Adapun tahapan yang dilakukan yaitu, Tahap Pendefinisian (Define), Tahapan Perancangan (Design), Tahap Pengembangan (Develop). Setelah melakukan proses pengembangan produk awal, maka LKS yang dikembangkan harus di uji cobakan terlebih dahulu. Validasi dilakukan oleh tiga ahli yaitu validasi ahli bahasa, validasi ahli materi, dan validasi ahli media. Apabila proses validasi telah dilakukan, maka proses selanjutnya melakukan proses uji coba small group dan respon guru kelas.

\section{Hasil Validaasi Ketiga Validator}

Hasil Validasi Ahli Bahasa

Validasi bahasa dilakukan guna melihat tata bahasa yang digunakan penulis dalam membuat LKS. Berikut ini aspek-aspek yang divalidasi oleh validator ahli bahasa beserta penilaian dan saran yang diberikan kepada penulis, yaitu sebagai berikut:

Tabel 3. Hasil Analisis Validasi Ahli Bahasa menggunakan Aiken's V

\begin{tabular}{llccc}
\hline $\begin{array}{l}\text { Aspek yang } \\
\text { dinilai }\end{array}$ & Indikator Penilaian & $\begin{array}{c}\text { Banyak } \\
\text { Butir }\end{array}$ & $\begin{array}{c}\text { Angka } \\
\text { Aiken's } \\
\boldsymbol{V}\end{array}$ & $\begin{array}{c}\text { Kriteria } \\
\text { Koofisiens } \\
\text { Aiken's } \boldsymbol{V}\end{array}$ \\
\hline & A. Lugas & 3 & 0,7 & Cukup Tinggi \\
\cline { 2 - 5 } $\begin{array}{l}\text { Kelayakan } \\
\text { Bahasa }\end{array}$ & B. Komunikatif & 1 & 0,7 & Cukup Tinggi \\
\cline { 2 - 5 } & C. Interaktif & 1 & 0,7 & Cukup Tinggi \\
\cline { 2 - 6 } & $\begin{array}{l}\text { Kesesuaian dengan } \\
\text { perkembangan } \\
\text { siswa }\end{array}$ & 3 & 0,7 & Cukup Tinggi \\
\cline { 2 - 6 } & E. $\begin{array}{l}\text { Kesesuaian dengan } \\
\text { kaidah bahasa }\end{array}$ & 6 & 0,7 & Cukup Tinggi \\
\hline & \multicolumn{2}{l}{ V rata-rata } & 0,7 & Cukup Tinggi \\
\hline
\end{tabular}

Tabel di atas menunjukkan hasil bahwa kelayakan bahasa di dalam LKS sudah baik dengan mendapatkan rata-rata 0,7 kategori cukup tinggi atau "valid" dari validator. Bahasa yang digunakan dalam LKS Matematika Berbasis Discovery Learning sudah sesuai dengan kaidah bahasa, lugas, komunikatif dan sesuai dengan perkembangan peseta didik. Sejalan dengan pendapat Akbar (Yerimadesi dkk, 2018:21) bahwa suatu bahan ajar yang berkualitas harus komunikatif, artinya isi dari bahan ajar mudah dicerna, sistematis, jelas dan tidak mengandung kesalahan bahasa.

Hasil Validasi Ahli Materi 
Validasi materi dilakukan guna melihat kelengkapan isi dan lan sebagainya yang digunakan penulis dalam membuat LKS. Berikut ini aspek-aspek yang divalidasi oleh validator beserta hasil yang diberikan oleh validator ahli materi yaitu sebagai berikut:

Tabel 4. Hasil Analisis Validasi Ahli Materi menggunakan Aiken's V

\begin{tabular}{lcccc}
\hline Aspek yang di nilai & $\begin{array}{c}\text { Indikator } \\
\text { Penilaian }\end{array}$ & $\begin{array}{c}\text { Banyak } \\
\text { Butir }\end{array}$ & $\begin{array}{c}\text { Angka } \\
\text { Aiken's } \\
\boldsymbol{V}\end{array}$ & $\begin{array}{c}\text { Kriteria } \\
\text { Koofisiens } \\
\text { Aiken's } \boldsymbol{V}\end{array}$ \\
\hline Kelengkapan isi & $\begin{array}{c}\text { Kesesuaian } \\
\text { materi dengan } \\
\text { KD }\end{array}$ & 3 & 0,7 & Cukup Tinggi \\
\cline { 2 - 5 } & $\begin{array}{c}\text { Keakuratan } \\
\text { materi }\end{array}$ & 4 & 0,775 & Tinggi \\
\cline { 2 - 5 } & $\begin{array}{c}\text { Mendorong } \\
\text { keingintahuan }\end{array}$ & 2 & 0,85 & Tinggi \\
\hline Kelayakan penyajian & $\begin{array}{c}\text { Teknik } \\
\text { penyajian }\end{array}$ & 1 & 0,7 & Cukup Tinggi \\
\cline { 2 - 5 } & $\begin{array}{c}\text { Pendukung } \\
\text { penyajian }\end{array}$ & 2 & 0,7 & Cukup Tinggi \\
\cline { 2 - 5 } & $\begin{array}{c}\text { Penyajian } \\
\text { pembelajaran }\end{array}$ & 1 & 0,7 & Cukup Tinggi \\
\cline { 2 - 5 } & $\begin{array}{c}\text { Kelengkapan } \\
\text { penyajian }\end{array}$ & 1 & 0,7 & Cukup Tinggi \\
\hline Aspek penilaian \\
Discovery Learning & $\begin{array}{c}\text { Hakikat } \\
\text { pembelajaran } \\
\text { Discovery } \\
\text { Leaning }\end{array}$ & 4 & 0,775 & Cukup Tinggi \\
\hline V rata-rata & & 0,73 & Cukup Tinggi \\
\hline
\end{tabular}

Tabel di atas menunjukkan hasil materi di dalam LKS sudah baik dengan mendapatkan rata-rata 0,73 kategori cukup tinggi dari atau "valid" dari validator ahli materi dan LKS Matematika Berbasis Discovery Learning. Penjelasan di atas menunjukkan bahwa semua aspek kelayakan materi sudah mencapai kevalidan untuk setiap aspek dan indikatornya. Salah satunya kesesuaian materi pada LKS dengan KD (Kompetensi Dasar). Hal yang sama dengan pernyataan Daryanto (Yerimadesi dkk, 2018:21) bahwa untuk menghasilkan bahwa bahan ajar yang baik, maka bahan ajar yang disusun berdasarkan pada Kompetensi Dasar.

Hasil Validasi Ahli Media

Validasi media dilakukan guna mengetahui kelayakan media dari LKS yang telah dikembangkan. Validator memberikan masukan dan saran mengenai keterpaduan warna yang di gunakan jenis huruf yang digunakan dan sebagainya. Berikut ini hasil dari validasi oleh ahli media. 
Tabel 5. Hasil Analisis Validasi Ahli Materi menggunakan Aiken's V

\begin{tabular}{ccccc}
\hline $\begin{array}{c}\text { Aspek yang di } \\
\text { nilai }\end{array}$ & $\begin{array}{c}\text { Indikator } \\
\text { Penilaian }\end{array}$ & $\begin{array}{c}\text { Banyak } \\
\text { Butir }\end{array}$ & $\begin{array}{c}\text { Angka } \\
\text { Aiken's } \boldsymbol{V}\end{array}$ & $\begin{array}{c}\text { Kriteria } \\
\text { Koofisiens } \\
\text { Aiken's } \boldsymbol{V}\end{array}$ \\
\hline $\begin{array}{c}\text { Kelayakan } \\
\text { Kegrafikan }\end{array}$ & Ukuran LKS & 2 & 0,7 & Cukup Tinggi \\
\cline { 2 - 5 } & $\begin{array}{c}\text { Desain Sampul } \\
\text { LKS }\end{array}$ & 7 & 0,79 & Cukup Tinggi \\
\cline { 2 - 5 } & Desain Isi LKS & 18 & 0,73 & Cukup Tinggi \\
\hline \multicolumn{2}{c}{ V rata-rata } & & 0,74 & Cukup Tinggi \\
\hline
\end{tabular}

Tabel di atas menunjukkan hasil kelayakan media dari aspek kegrafikan LKS sudah baik dengan mendapatkan rata-rata 0,74 kategori cukup tinggi atau "valid" dari validator ahli media. Data di atas menunjukkan bahwa ukuran, desain sampul LKS dan desain isi LKS sudah baik dan dapat menarik perhatian siswa untuk belajar menggunakan LKS tersebut. Sejalan dengan pernyataan Hamdani (Yerimadesi dkk, 2018:21) bahwa tata letak yang baik akan menimbulkan daya tarik tersendiri terhadap minat belajar siswa. Berikut ini penjelasan mengenai hasil dari proses validasi yang telah dilakukan pada ketiga validator dalam memberi masukan dan saran serta penilalian mengenai LKS yang telah dikembangkan.

Tabel 6. Hasil Analisis Ketiga Validasi Ahli menggunakan Aiken's V

\begin{tabular}{ccccc}
\hline No & Nama Ahli & \multicolumn{2}{c}{ Skor yang diperoleh } \\
\hline 1 & Dr. Rusmana Dewi, M.Pd & 0,7 & - & - \\
\hline 2 & Citra Haziariah, S.Pd. & - & 0,73 & - \\
\hline 3 & Dr. Dodik Mulyono, M.Pd & - & - & 0,74 \\
\hline Jumlah & 0,7 & 0,73 & 0,74 \\
\hline Rata-rata & & 0,72 & \\
\hline
\end{tabular}

Tabel di atas menunjukkan bahwa LKS Matematika Berbasis Discovery Learning Materi Sattistika untuk Siswa Kelas IV SD Negeri 46 Lubuklinggau mendapatkan rata-rata 0,72 dimana berdasarkan interpretasi validitas Aiken's $V$ LKS masuk dalam kategori $0,60 \leq \mathrm{V} \geq 0,80$ cukup tinggi atau LKS dikatakan sudah "valid". Semua hasil dari ketiga validator sudah menunjukkan bahwa LKS sudah sesuai dan valid dimana pernyataan tersebut didukung denga $\mathrm{n}$ pendapat para ahli yang sudah dijelaskan pada setiap uji coba validasi.

\section{Hasil Analisis Kepraktisan}

Analisis Kepraktisan Guru

Analisis kepraktisan guru dilakukan bersamaan dengan uji coba small group.

Berikut ini hasil analisis data uji coba kepraktisan yang dilakukan oleh guru: 
Tabel 7. Hasil Analisis Uji Kepraktisan Guru

\begin{tabular}{|c|c|c|c|c|c|}
\hline No & Aspek & Indikator Penilaian & $\begin{array}{c}\text { Banyak } \\
\text { Butir }\end{array}$ & Persentase & $\begin{array}{l}\text { Kriteria } \\
\text { Persentase }\end{array}$ \\
\hline \multirow{3}{*}{1} & \multirow{3}{*}{$\begin{array}{l}\text { Komponen } \\
\text { perumusan } \\
\text { tujuan } \\
\text { pembelajaran }\end{array}$} & $\begin{array}{ll}\text { A. } & \text { Kejelasan } \\
\text { dalam } \\
\text { Kompetensi } \\
\text { Inti dan dalam } \\
\text { Kompetensi } \\
\text { Dasar }\end{array}$ & 1 & $100 \%$ & $\begin{array}{l}\text { Sangat } \\
\text { praktis }\end{array}$ \\
\hline & & $\begin{array}{ll}\text { B. } & \text { Kesesuaian } \\
\text { pada indikator } \\
\text { dengan tujuan }\end{array}$ & 1 & $100 \%$ & $\begin{array}{l}\text { Sangat } \\
\text { praktis }\end{array}$ \\
\hline & & $\begin{array}{ll}\text { C. } & \text { Kesesuaian } \\
\text { pada indikator } \\
\text { dengan tingkat } \\
\text { perkembangan }\end{array}$ & 1 & $75 \%$ & Praktis \\
\hline 2 & $\begin{array}{l}\text { Komponen } \\
\text { kegrafikan }\end{array}$ & $\begin{array}{ll}\text { A. } & \text { Kesesuaian } \\
\text { penggunaan } \\
\text { ilustrasi/gamb } \\
\text { ar-gambar } \\
\text { dengan materi }\end{array}$ & 1 & $100 \%$ & $\begin{array}{l}\text { Sangat } \\
\text { praktis }\end{array}$ \\
\hline \multirow[t]{2}{*}{3} & \multirow{2}{*}{$\begin{array}{l}\text { Komponen } \\
\text { pada bahasa }\end{array}$} & $\begin{array}{l}\text { A. Bahasa yang } \\
\text { digunakan } \\
\text { sesuai dengan } \\
\text { kaidah bahasa } \\
\text { Indonesia }\end{array}$ & 1 & $75 \%$ & Praktis \\
\hline & & $\begin{array}{ll}\text { B. } & \text { Kemudahan } \\
\text { memahami } \\
\text { bahasa yang } \\
\text { digunakan }\end{array}$ & 1 & $100 \%$ & $\begin{array}{l}\text { Sangat } \\
\text { praktis }\end{array}$ \\
\hline \multirow{5}{*}{4} & \multirow{5}{*}{$\begin{array}{l}\text { Komponen } \\
\text { materi }\end{array}$} & $\begin{array}{ll}\text { A. } & \text { Kejelasan } \\
& \text { langkah- } \\
& \text { langkah } \\
& \text { penyelesaian }\end{array}$ & 1 & $75 \%$ & Praktis \\
\hline & & $\begin{array}{ll}\text { B. } & \text { Kemenarikan } \\
\text { tampilan LKS }\end{array}$ & 1 & $100 \%$ & $\begin{array}{l}\text { Sangat } \\
\text { praktis }\end{array}$ \\
\hline & & $\begin{array}{ll}\text { C. } & \text { Kesesuaian } \\
\text { materi dengan } \\
\text { kompetensi } \\
\text { dasar }\end{array}$ & 1 & $100 \%$ & $\begin{array}{l}\text { Sangat } \\
\text { praktis }\end{array}$ \\
\hline & & $\begin{array}{l}\text { D. Kesesuaian } \\
\text { materi dengan } \\
\text { indikator } \\
\text { pencapaian } \\
\text { kompetensi }\end{array}$ & 1 & $100 \%$ & $\begin{array}{l}\text { Sangat } \\
\text { praktis }\end{array}$ \\
\hline & & E. Penggunaan & 1 & $100 \%$ & Sangat \\
\hline
\end{tabular}




\begin{tabular}{ccccc}
\hline No Aspek & Indikator Penilaian & $\begin{array}{c}\text { Banyak } \\
\text { Butir }\end{array}$ & Persentase & $\begin{array}{c}\text { Kriteria } \\
\text { Persentase }\end{array}$ \\
\hline model & & praktis \\
Discovery & & \\
Learning & & \\
dengan materi & & \\
\hline
\end{tabular}

Berdasarkan keterangan di atas, respon guru dihitung berdasarkan persentase dari 11 item respon guru yang apa bila guru memberikan penilaian dengan rentang $61 \%-80 \%$ kriteria praktis apabila penilaian yang diberikan $81-100 \%$, maka sangat praktis. Artinya LKS Matematika Berbasis Discovery Learning pada Materi Statistika untuk Siswa Kelas IV SD Negeri 46 Lubuklinggau tidak perlu untuk melakukan perbaikan. Berikut ini akan diuraikan secara rinci dan singkat keseluruhan hasil analisis yang diberikan oleh guru terhadap LKS Matematika Berbasis Discovery Learning pada Materi Statistika untuk Siswa Kelas IV SD Negeri 46 pada tabel.

Tabel 8. Hasil Analisis Persentase Respon Guru

\begin{tabular}{clccc}
\hline No & \multicolumn{1}{c}{ Aspek } & Responden & Persentase & $\begin{array}{c}\text { Kriteria } \\
\text { Respon }\end{array}$ \\
\hline 1 & $\begin{array}{l}\text { Komponen perumusan } \\
\text { tujuan pembelajaran }\end{array}$ & 1 orang & $91,6 \%$ & Sangat praktis \\
\hline 2 & Komponen kegrafikan & 1 orang & $100 \%$ & Sangat praktis \\
\hline 3 & Komponen pada bahasa & 1 orang & $87,5 \%$ & Sangat praktis \\
\hline 4 & Komponen materi & 1 orang & $95 \%$ & Sangat praktis \\
\hline Rata-rata & & $93,5 \%$ & Sangat praktis \\
\hline
\end{tabular}

Berdasarkan hasil perhitungan tabel di atas, diketahui bahwa uji kepraktisan guru yang diberikan berdasarkan 11 item mendapatkan kategori sangat praktis. Guru kelas memberikan penilaian yang sangat bagus dimana setelah dianalisis dari setiap aspek, yaitu aspek Komponen perumusan tujuan pembelajaran 91,6\%\%, aspek Komponen pada bahasa $87,5 \%$ dan aspek Komponen materi 95\% dengan rat-rata 93,5\%. Sehingga LKS Matematika Berbasis Discovery Learning pada Materi Statistika untuk Siswa Kelas IV SD Negeri 46 dapat digunakan dalam proses pembelajaran.

\section{Analisis Kepraktisan Peserta Didik}

Hasil kepartisan untuk penelitian ini yaitu penulis melakukan uji coba small group yang dilakukan kepada enam orang siswa yang memiliki kemampuan tinggi, sedang dan rendah. Penelitian dilakukan pada tanggal 29 April 2021. Penelitian dilakukan selama 1 minggu. Dimana untuk pertemuan pertama penulis melakukan proses pembelajaran selam 1 jam pelajaran (2x35 menit) untuk menjelaskan setiap pembelajaran kepada siswa. Siswa mengerjakan kegiatan ayo berlatih pada pembelajaran 1. Pembelajaran 2, 3 dan 4 penulis memberikan LKS kepada siswa untuk mempelajari LKS tersebut di rumah. Setelah itu penulis mengumpulkan siswa kembali pada tanggal 6 Mei 2021 untuk memberikan angket kepraktisan kepada siswa serta memberi komentar serta penilaian mengenai LKS yang telah mereka pelajari di rumah. Dari kriteria penilaian kepraktisan, produk penulis mendapatkan nilai (sangat 
praktis) dari keenam siswa. Berikut ini hasil analisis respon peserta didil uji coba small group pada siswa kelas IV SD Negeri 46 Lubuklinggau.

Tabel 9. Hasil Analisis Respon Peserta Didik Uji Coba Small Group

\begin{tabular}{|c|c|c|c|c|c|}
\hline No & Aspek & Indikator & $\begin{array}{c}\text { Banyak } \\
\text { Butir }\end{array}$ & Persentase & $\begin{array}{l}\text { Kriteria } \\
\text { Persentase }\end{array}$ \\
\hline \multirow[t]{2}{*}{1} & \multirow[b]{2}{*}{ Kemudahan } & $\begin{array}{l}\text { LKS mudah digunakan } \\
\text { dalam proses pembelajaran }\end{array}$ & 2 & $100 \%$ & Sangat praktis \\
\hline & & $\begin{array}{ll}\text { Memudahkan } & \text { dalam } \\
\text { memahami } & \text { materi } \\
\text { pelajaran } & \end{array}$ & 2 & $100 \%$ & Sangat praktis \\
\hline \multirow[t]{3}{*}{2} & \multirow{3}{*}{$\begin{array}{l}\text { Kemenarik } \\
\text { an }\end{array}$} & 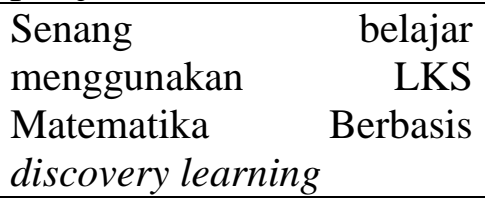 & 1 & $100 \%$ & Sangat praktis \\
\hline & & $\begin{array}{lr}\text { Penggunaan } & \text { LKS } \\
\text { Matematika Berbasis } \\
\text { discovery learning tidak } \\
\text { membosankan }\end{array}$ & 1 & $100 \%$ & Sangat praktis \\
\hline & & Penampilan LKS menarik & 3 & $100 \%$ & Sangat Praktis \\
\hline \multirow[t]{2}{*}{3} & \multirow[t]{2}{*}{$\begin{array}{l}\text { Keterbantu } \\
\text { an }\end{array}$} & $\begin{array}{ll}\text { Membantu dalam } & \text { proses } \\
\text { belajar karena sesuai } \\
\text { dengan gaya belajar }\end{array}$ & 2 & $100 \%$ & Sangat praktis \\
\hline & & $\begin{array}{l}\text { Membantu untuk belajar } \\
\text { lebih aktif }\end{array}$ & 3 & $94,3 \%$ & Sangat praktis \\
\hline 4 & $\begin{array}{l}\text { Pemecahan } \\
\text { masalah }\end{array}$ & $\begin{array}{l}\text { Meningkatkan penalaran } \\
\text { individu }\end{array}$ & 2 & $91,5 \%$ & Sangat praktis \\
\hline
\end{tabular}

Respon peserta didik dihitung berdasarkan persentase dari 16 item respon peserta didik berdasarkan 4 aspek dan 8 indikator yang apa bila peserta didik memberikan penilaian dengan rentang $61 \%-80 \%$ kriteria praktis apabila penilaian yang diberikan 81-100, maka sangat praktis. Artinya LKS Matematika Berbasis Discovery Learning pada Materi Statistika untuk Siswa Kelas IV SD Negeri 46 Lubuklinggau tidak perlu untuk melakukan perbaikan. Berikut ini akan diuraikan secara rinci dan singkat keseluruhan hasil analisis respon keenam peserta didik terhadap LKS Matematika Berbasis Discovery Learning pada Materi Statistika untuk Siswa Kelas IV SD Negeri 46 pada tabel 4.13

Tabel 10. Hasil Analisis Persentase Respon Peserta Didik Uji Small Group

\begin{tabular}{llccc}
\hline No & \multicolumn{1}{c}{ Aspek } & Responden & Persentase & $\begin{array}{c}\text { Kriteria } \\
\text { Respon }\end{array}$ \\
\hline 1 & Kemudahan & 6 orang & $100 \%$ & Sangat praktis \\
\hline 2 & Kemenarikan & 6 orang & $100 \%$ & Sangat praktis \\
\hline 3 & Keterbantuan & 6 orang & $97,15 \%$ & Sangat praktis \\
\hline 4 & Pemecahan masalah & 6 orang & $91,5 \%$ & Sangat praktis \\
\hline \multicolumn{2}{r}{ Rata-rata } & & $97,16 \%$ & Sangat praktis \\
\hline
\end{tabular}

Berdasarkan hasil perhitungan tabel di atas, diketahui bahwa respon siswa 
yang diberikan dengan menggunakan 16 item mendapatkan kategori sangat praktis. Dari 6 peserta didik memberikan penilaian yang sangat bagus dimana setelah dianalisis dari setiap aspek, yaitu aspek kemudahan 100\%. Data ini menunjukkan bahwa LKS ini tergolong mudah digunakan dalam proses pembelajaran. Aspek kemenariakan $100 \%$. Data ini menjelaskan bahwa LKS memiliki kemenarikan yang cukup tinggi, dilihat dari desain, perpaduan warna dan gambar yang digunakan. sehingga respon dan nilai yang didapatkan penulis itu sangat baik. Aspek keterbantuan 97,15\%, dan Aspek pemecahan masalah 91,5\% dikategorikan sangat praktis. Daryanto (Yerimadesi dkk, 2018:22) menyatakan bahwa pertimbangan praktikalitas dapat dilihat dari aspek-aspek kemudahan penggunaannya. Disimpulkan bahwa, LKS Matematika Berbasis Discovery Learning pada Materi Statistika untuk Siswa Kelas IV SD Negeri 46 dapat digunakan dalam proses pembelajaran.

\section{Hasil Seluruh Analisis Kepraktisan LKS}

Hasil keseluruhan dari proses kepraktisan LKS yang diuji cobakan siswa dan pemberian respon dari guru terhadap LKS yang dikembangkan mendapatkan skor ratarata 95,32\% dengan kriteria sangat praktis. Berikut ini rekapitulasi hasil keseluruhan penilaian kepraktisan dari guru dan siswa.

Tabel 11. Hasil Seluruh Analisis Kepraktisan LKS

\begin{tabular}{cccccc}
\hline No & Penilaian & $\begin{array}{c}\text { Jumlah Butir } \\
\text { Pertanyaan }\end{array}$ & $\begin{array}{c}\text { Skor yang } \\
\text { diperoleh }\end{array}$ & Persentase & Kriteria \\
\hline 1 & Citra Haziariah, S.Pd & 11 & 8 & $72,72 \%$ & Praktis \\
\hline 2 & $\begin{array}{l}\text { 6 Siswa Kela IV.a SD } \\
\text { Negeri } \\
\text { Lubuklinggau }\end{array}$ & 96 & 94 & $97,91 \%$ & $\begin{array}{l}\text { Sangat } \\
\text { Praktis }\end{array}$ \\
\hline Total & & & & \\
\hline & 107 & 102 & $95,32 \%$ & $\begin{array}{l}\text { Sangat } \\
\text { Praktis }\end{array}$ \\
\hline
\end{tabular}

\section{PENUTUP}

Alur pengembangan yang digunakan adalah model pengembangan 4-D memiliki 4 tahapan dalam pelaksanaanya yaitu: pendefinisian (Define), tahap perancangan (Design), tahap pengembangan, dan tahap pendiseminasian (Dessiminate). LKS Matematika Berbasis Discovery Learning pada Materi Statistika untuk Siswa Kelas IV SD Negeri 46 ini dinyatakan valid dan praktis. dikatakan LKS ini valid dilihat dari hasil validasi ketiga ahli yang menyatakan LKS dapat digunakan dengan revisi disertai dengan pemberian nilai pada angket dengan pemerolehan nilai menunjukkan kriteria valid untuk LKS yang dikembangkan. Sedangkan untuk kepraktisan dilihat dari respon guru dan uji coba peserta didik.

\section{DAFTAR PUSTAKA}

Arifin, Z. A. I., \& Dzikriyah, N. A. S. (2019). Pengembangan LKS Matematika dengan Pendekatan Saintifik Pokok Bahasan Polinomial untuk SMA Kelas XI. Jurnal Pendidikan Matematika, 3(1), 9-15.

Aziz, A. (2017). Komunikasi Pendidik dan Peserta Didik dalam Pendidikan Islam. Jurnal Mediakita, 1(2),173-184.

Azwar. S. (2015). Reabilitas dan Validitas. Yogyakarta : Pustaka Belajar.

Cintia, N. I., dkk. (2018). Penerapan Model Pembelajaran Discovery Learning 
untuk Meningkatkan Kemampuan Berfikir Kreatif dan Hasil Belajar

Siswa. Jurnal Perspektif Ilmu Pendidikan, 32(1), 69-77.

Febriandi, R. (2019). Validitas LKS Matematika dengan Pendekatan Saintifik Berbasis Outdoor pada Materi Bangun Datar. Jurnal Pembelajaran dan Pengajaran Pendidikan Dasar, 2(2), 148-158.

Fitria, E., dkk. (2018). Pengembangan Lembar Keja Siswa (LKS) Berbasis Contextual Teaching and Learning (CTL) Materi Sistem Persamaan Linear Tiga Variabel Siswa Kelas X MIA SMA N 9 Kota Jambi. Jurnal Pendidikan Matematika, 2(1), 7-12.

Fitriyana, N., \& Lucy, A. P. (2020). Pengembangan Lembar Kerja Siswa Berbasis Discovery Learning. Jurnal Pendidikan Matematika, 3(1), 17-25.

Hendriana, E. C., \& Amol, J. (2016). Implementasi Pendidikan Karakter Di Sekolah Melalui Keteladanan dan Pembiasaan. Jurnal Pendidikan Dasar Indonesia, $1(2), 25-29$.

Hidayat, A., \& Indra, I. Pengembangan LKS Berbasis RME dengan Pendekatan Problem Solving untuk Memfailitasi Kemampuan Pemecahan Masalah Matematis Siswa. Jurnal Cendekia, 1(2), 51-63.

Ikhsan, A., dkk. (2017). Pemanfaatan Lingkungan Sekolah sebagai Sumber Belajar di SD rnal Negeri 2 Teunom Aceh Jaya. Jurnal Ilmiah Pendidikan Guru Sekolah Dasar, 2(1), 1-11.

Ismatulloh, K. (2017). Penerapan Metode Pembelajaran Resitasi dalam Pembelajaran Matematika Dasar. Jurnal Pendidikan Informatika, 1(1), 24-28.

Musfiqon. (2012). Pengembangan Media Belajar dan Sumber Belajar. Jakarta: Prestasi Pustakakarya.

Pane, A., \& Muhammad, D.D. (2017). Belajar dan Pembelajaran. Jurnal Kajian Ilmuilmu Keislaman, 3(2), 333-352.

Rosarina, G., dkk. (2016). Penerapan Model Discovery Learning untuk Meningkatkan Hasil Belajar Siswa pada Materi Perubahan Wujud Benda. Jurnal Pena Ilmiah, 1(1), 371-380.

Shalikhah, N. D. (2016). Pengembangan Lembar Kerja Siswa (LKS) IPS Berbasis Pendekatan Scientific. Tarbiya Tuna, 7(2), 144-166.

Sintawati, M., dkk. (2020). Penggunaan Realistic Mathematic Education dalam Pembelajaran Matematika di Sekolah Dasar. Jurnal Cakrawala Pendas, 6(2), 93-101.

Yerimadesi., dkk (2018). Validitas dan Praktikalitas Reaksi Redoks dan Sel Elektrokimia Berbasis Guided Discovery Learning untuk SMA. Jurnal Eksakta Pedidikan (JEP), (2)1, 17-24. 